Disclosure of Interests: David Simon Grant/research support from: Novartis, Consultant for: Lilly, Speakers bureau: Janssen, Andreas Berlin: None declared, Koray Tascilar: None declared, Sara Bayat: None declared, Klaus Engelke: None declared, Jürgen Rech Grant/research support from: Bristol-Myers Squibb and Celgene (greater than $\$ 10,000$ ), Consultant for: Bristol-Myers Squibb, Celgene, Chugai, GlaxoSmithKline, Janssen, Eli Lilly, Novartis, Roche, Sanofi Aventis, and UCB (in total more than \$10,000), Speakers bureau: Bristol-Myers Squibb, Celgene, Chugai, GlaxoSmithKline, Janssen, Eli Lilly, Novartis, Roche, Sanofi Aventis, and UCB (in total more than \$10,000), Camille Figuereido: None declared, Axel Hueber Grant/research support from: Novartis, Pfizer, Lilly, Consultant for: Lilly, GSK, Novartis, Janssen, Celgene, Abbvie, Roche, Speakers bureau: Lilly, Janssen, Novartis, Celgene, Biogen, Abbvie, BMS, Georg Schett: None declared, Arnd Kleyer Grant/research support from: Lilly, Consultant for: Lilly, Speakers bureau: Abbvie

DOI: 10.1136/annrheumdis-2019-eular.2757

\section{THU0621 VERY LOW PREVALENCE OF ULTRASOUND DETERMINED TENDON ABNORMALITIES IN HEALTHY SUBJECTS THROUGHOUT THE AGE RANGE: OMERACT ULTRASOUND MINIMAL DISEASE STUDY}

Jeanette Trickey ${ }^{1}$, Ilfita Sahbudin ${ }^{1}$, Alessandra Bortoluzzi ${ }^{2}$, Annamaria lagnocco $^{3}$, Carlos Pineda $^{4}$, Cesar Sifuentes-Cantú ${ }^{\text {, Coziana Ciurtin }}{ }^{6}$, Cristina Reategui Sokolova ${ }^{4}$, Daniela Fodor ${ }^{7}$, Ellen-Margrethe Hauge ${ }^{8}$, Esperanza Naredo ${ }^{5}$, Florentin Ananu Vreju ${ }^{9}$, Garifallia Sakellariou ${ }^{10}$ George Bruyn ${ }^{11}$, Georgios Filippou², Giuliana M.C. La Paglia ${ }^{5}$, Gustavo Leon ${ }^{4}$, Helen Keen ${ }^{12}$, Hilde Berner Hammer ${ }^{13}$, Ilaria Tinazzi ${ }^{14}$, Irene Azzolin ${ }^{3}$, Jacek Fliciński ${ }^{15}$, James Wilton ${ }^{6}$, Kei Ikeda ${ }^{16}$, Lene Terslev ${ }^{17}$, Mads AmmitzbøllDanielsen ${ }^{17}$, Mads Nyhuus Bendix Rasch ${ }^{8}$, Marcin Milchert ${ }^{15}$, Maria Stoenoiu ${ }^{18}$, Marion Kortekaas ${ }^{19}$, Marwin Gutierrez ${ }^{4}$, Mihaela Maruseac ${ }^{18}$, Mohammed A Mortada $^{20}$, Philippe Carron ${ }^{21}$, Rositsa Karalilova ${ }^{22}$, Ruth Wittoek ${ }^{21}$, Sarah Ohrndorf ${ }^{23}$, Takeshi Suzuki ${ }^{24}$, Teodora Serban ${ }^{3}$, MariaAntonietta D'agostino ${ }^{25}$, Andrew Filer ${ }^{1}$, OMERACT US Group. ${ }^{1} / I A$, Birmingham, United Kingdom; ${ }^{2}$ UoF, Cona, Italy; ${ }^{3}$ ARC, Turin, Italy, ${ }^{4}$ INR, Mexico City, Mexico; ${ }^{5}$ UFJD, Madrid, Spain; ${ }^{6}$ UCL, London, United Kingdom; ${ }^{7} I H U$, Cluj-Napoca, Romania; ${ }^{8} \mathrm{AUH}$, Aarhus, Denmark; ${ }^{9}$ UoC, Craiova, Romania; ${ }^{10}$ UoP, Pavia, Italy, ${ }^{11}$ MCG, Lelystad, Netherlands; ${ }^{12}$ UWA, Perth, Australia; ${ }^{13} \mathrm{DH}$, Oslo, Norway; ${ }^{14} \mathrm{SCH}$, Verona, Italy; ${ }^{15} \mathrm{PUM}$, Szczecin, Poland; ${ }^{16} \mathrm{CUH}$, Chiba, Japan; ${ }^{17} \mathrm{CUH}$, Copenhagen, Denmark; ${ }^{18}$ UCLB, Brussels, Belgium; ${ }^{19}$ LUM, Leiden, Netherlands; ${ }^{20} \mathrm{ZU}$, Zagazig, Egypt, ${ }^{21} \mathrm{GUH}$, Ghent, Belgium; ${ }^{22} \mathrm{UHK}$, Plovdiv, Bulgaria; ${ }^{23} \mathrm{CU}$, Berlin, Germany, ${ }^{24} J R C$, Tokyo, Japan; ${ }^{25}$ APHP, Paris, France

Background: Tenosynovitis (TS) is a common, often clinically undetectable finding in Rheumatoid Arthritis (RA). Recent data showed TS on ultrasound (US) has a role in predicting outcome in early disease and flare in clinical remission. However data is limited on US measured TS in healthy subjects (HS), none specifically encompassing the older age range when RA commonly presents.

Objectives: This OMERACT study aimed to determine prevalence of US measured tendon abnormalities in HS throughout the age range.

Methods: Adult HS without: joint pain (VAS <10/100), hand osteoarthritis (ACR criteria), or inflammatory arthritis were recruited in 23 international centres from Aug 2017-Dec 2018. MCP, PIP and wrist joints were clinically examined. Bilateral digit flexor (DF) 1-5 and extensor carpi ulnaris (ECU) tendons were scanned for tenosynovial hypertrophy (TSH) and power Doppler (PD) signal and graded (OMERACT US scoring system ${ }^{1}$ ). A comparison cohort of DMARD-naive patients with RA (ACR-EULAR 2010 and/or 1987 criteria) at presentation was taken from the Birmingham Early Arthritis (BEACON) inception cohort, who underwent identical tendon US assessment. They were grouped into $\leq 12$ and $>12$ weeks from symptom onset.

Results: Data from 899 HS and 144 RA patients were included.

\begin{tabular}{|c|c|c|c|c|c|c|c|}
\hline & $\begin{array}{c}\text { HS 18- } \\
39 \mathrm{y}\end{array}$ & $\begin{array}{c}\text { HS } 40- \\
59 \mathrm{y}\end{array}$ & $\begin{array}{c}\text { HS } \\
\geq 60 \mathrm{y}\end{array}$ & $\begin{array}{l}\text { RA } \\
\leq 12\end{array}$ & $\begin{array}{c}\mathrm{RA}> \\
12\end{array}$ & $\begin{array}{l}5 \text { groups } \\
p \text { value }\end{array}$ & $\begin{array}{l}\mathrm{RA} \leq 12 \text { vs } \\
>12 \mathrm{p} \text { value }\end{array}$ \\
\hline$n$ & 408 & 311 & 180 & 30 & 114 & & \\
\hline Age, y (IQR) & $\begin{array}{c}29 \\
(25-33)\end{array}$ & $\begin{array}{c}49 \\
(44-55)\end{array}$ & $\begin{array}{l}68 \\
(62- \\
72)\end{array}$ & $\begin{array}{c}58(52- \\
69)\end{array}$ & $\begin{array}{c}53(42- \\
65)\end{array}$ & $<0.001$ & 0.03 \\
\hline Female (\%) & $\begin{array}{l}270 \\
(66)\end{array}$ & $\begin{array}{l}270 \\
(83)\end{array}$ & $\begin{array}{l}114 \\
(62)\end{array}$ & $20(67)$ & $86(75)$ & $<0.001$ & 0.2 \\
\hline $\begin{array}{l}\text { DAS } 28 \text { CRP } \\
\text { (IQR) }\end{array}$ & - & - & - & $\begin{array}{c}5.4 \\
(4.2- \\
6.1)\end{array}$ & $\begin{array}{c}4.8 \\
(4.1- \\
5.7)\end{array}$ & - & 0.1 \\
\hline $\begin{array}{l}\text { Tender joint }{ }^{\star} \\
\text { (IQR) }\end{array}$ & 0 & 0 & 0 & $\begin{array}{c}18(10- \\
23)\end{array}$ & $\begin{array}{c}17(11- \\
29)\end{array}$ & $<0.001$ & 0.9 \\
\hline 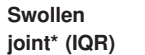 & 0 & 0 & 0 & $\begin{array}{c}8(3- \\
18)\end{array}$ & $6(3-9)$ & $<0.001$ & 0.1 \\
\hline
\end{tabular}

$\geq 1(\%)$

${ }^{*}$ RA had $66 / 68$ joint count

Prevalence of TSH and particularly PD abnormalities in HS was very low at all ages, and was all grade 1 except in one individual ECU tendon. ECU TSH grade $\geq 1$ was more common than DF grade $>1$ in the older HS groups, and less common in the $18-39$ age group $(p=0.011)$. TSH and PD of grade $\geq 1$ were common in RA patients, with DF PD abnormalities more common in early disease $(p=0.02)$.

Conclusion: Low prevalence of TSH or PD abnormalities in tendons of HS even in old age suggests US determined TS will be a robust tool in clinically managing $R A$.

\title{
REFERENCES:
}

[1] Naredo E, D'Agostino MA, et al. Reliability consensus-based US score TS RA. ARD.2013;72(8):1328-34

Disclosure of Interests: Jeanette Trickey: None declared, Ilfita Sahbudin: None declared, Alessandra Bortoluzzi: None declared, Annamaria lagnocco: None declared, Carlos Pineda: None declared, Cesar SifuentesCantú: None declared, Coziana Ciurtin: None declared, Cristina Reategui Sokolova: None declared, Daniela Fodor: None declared, Ellen-Margrethe Hauge: None declared, Esperanza Naredo Consultant for: Abbvie, Speakers bureau: AbbVie, Roche, Bristol-Myers Squibb, Pfizer, UCB, Lilly, Novartis, Janssen, and Celgene $\mathrm{GmbH}$, Florentin Ananu Vreju Consultant for: abbvie and novartis, Speakers bureau: abbvie, novartis, pfizer, sandoz, eli lilly, ucb pharma, Garifallia Sakellariou: None declared, George Bruyn : None declared, Georgios Filippou Speakers bureau: Laborest, Abbvie, BMS, Sanofi, Giuliana M.C. La Paglia : None declared, Gustavo Leon: None declared, Helen Keen: None declared, Hilde Berner Hammer Grant/research support from: AbbVie, Pfizer and Roche, Paid instructor for: AbbVie, Pfizer, UCB, Novartis, Roche, Speakers bureau: AbbVie Pfizer, UCB, Novartis, Roche, llaria Tinazzi: None declared, Irene Azzolin: None declared, Jacek Fliciński: None declared, James Wilton: None declared, Kei Ikeda: None declared, Lene Terslev Speakers bureau: Speakers fee from : Roche, Novartis, Pfizer, MSD, BMS, Celgene, Mads Ammitzbøll-Danielsen: None declared, Mads Nyhuus Bendix Rasch: None declared, Marcin Milchert: None declared, Maria Stoenoiu Grant/research support from: Abbvie, Roche, Wyeth, Marion Kortekaas: None declared, Marwin Gutierrez: None declared, Mihaela Maruseac: None declared, Mohammed A Mortada: None declared, Philippe Carron: None declared Rositsa Karalilova: None declared, Ruth Wittoek: None declared, Sarah Ohrndorf: None declared, Takeshi Suzuki: None declared, Teodora Serban: None declared, Maria-Antonietta d'Agostino: None declared, Andrew Filer: None declared

DOI: 10.1136/annrheumdis-2019-eular.4746

\section{THU0622 MRI OF THE CRANIO-CERVICAL JUNCTION IN RHEUMATOID ARTHRITIS - DEFINITION OF NORMAL AND PATHOLOGICAL FINDINGS}

Katharina Ziegeler ${ }^{1}$, Christoph Korsing ${ }^{2}$, Mattias Bollow ${ }^{3}$, Kay Geert A. Hermann ${ }^{1}$. ${ }^{1}$ Charité - Universitätsmedizin Berlin, Radiology, Berlin, Germany, ${ }^{2}$ ElisabethKrankenhaus, Internal Medicine, Essen, Germany; ${ }^{3}$ Augusta-Kranken-Anstalt, Bochum, Diagnostic and Interventional Radiology and Nuclear Medicine, Bochum, Germany

Background: In rheumatoid arthritis (RA), disease involvement at the cervical spine is common and may lead to malposition of the dens axis resulting in severe neurological impairment. To date, malalignment is mostly described by X-rays.

Objectives: The aim of this investigation was to systematically define osseous and ligamentous MRl-findings in cranio-cervical RA in comparison to a control group without the disease.

Methods: MRI datasets of patients with cranio-cervical RA were identified retrospectively from the institutional image database and matched regarding age and gender with control patients. All image datasets were systematically reviewed for: position and morphology of dens axis (including erosions and osteitis); width and angle of the cranio-cervical joints; length, angle and visibility of peridental ligaments; vascularization of peridental 